\title{
华北地区农业水资源现状和未来保障研究
}

\author{
黄峰 $^{1}$, 杜太生 $^{2}$, 王素芬 $^{2}$, 梅旭荣 $^{3}$, 烡道枝 $^{3}$, 陈源泉 ${ }^{4}$, 康绍忠 ${ }^{2}$ \\ (1. 中国农业大学土地科学与技术学院，北京 100193；2. 中国农业大学水利与土木工程学院，北京 100083; \\ 3. 中国农业科学院农业环境与可持续发展研究所, 北京 100081；4. 中国农业大学农学院，北京 100193）
}

摘要：华北地区是我国重要的粮食和农产品生产基地，对保障国家的粮食和食物安全至关重要。华北用仅占全国 6\% 的水资 源支撑了占全国 $18 \%$ 的耕地并生产出占全国 $23 \%$ 的粮食。但这个巨大成就是以极大的资源环境和生态成本为代价的。本文 回顾华北粮食生产和用水的历史性成就, 总结现在面临的主要问题和挑战, 然后应用国际水资源研究界广泛应用的农业用水 管理的综合分析框架, 系统分析 1998-2015 年华北地区水资源、农业用水以及用水效率和水分生产力, 在此基础上尝试提 出了未来保障华北地区食物安全的战略和政策途径。

关键词: 食物安全; 农业用水; 水分利用效率; 作物水分生产力

中图分类号: S-01 文献标识码：A

\section{Current Situation and Future Security of Agricultural Water Resources in North China}

\author{
Huang Feng ${ }^{1}$, Du Taisheng ${ }^{2}$, Wang Sufen ${ }^{2}$, Mei Xurong ${ }^{3}$, Gong Daozhi ${ }^{3}$, \\ Chen Yuanquan ${ }^{4}$, Kang Shaozhong ${ }^{2}$
}

(1. College of Land Science and Technology, China Agricultural University, Beijing 100193, China; 2. College of Water Resources and Civil Engineering, Beijing 100081, China; 3. Institute of Environment and Sustainable Development in Agriculture, Chinese Academy of Agricultural Sciences, Beijing 100081, China; 4. College of Agronomy and Biotechnology, China Agricultural University,

Beijing 100193, China)

\begin{abstract}
North China is one of the major breadbaskets in China and is critical in ensuring food security of the nation. It sustained $18 \%$ of national total arable land, and $23 \%$ of national total grain crop output using only $6 \%$ of national total water resources. However, such impressive accomplishments were achieved at huge costs incurred in resources, environment, and ecosystem. We first presented accomplishments, current situations, and main challenges facing agriculture and water use in North China. Then, using an integrated framework in agricultural water management widely adopted by international water research communities, we reviewed the trajectory of agricultural development and its associated water withdrawal, water use efficiencies, and productivities in North China from 1998 to 2015 , from which some major experiences and lessons were derived. We then tentatively proposed policy and strategy pathways to ensure food security in North China in the future.
\end{abstract}

Keywords: food security; agricultural water use; water use efficiency; crop water productivity

收稿日期 : 2019-09-02; 修回日期 : 2019-09-08

通讯作者: 康绍忠, 中国农业大学教授, 中国工程院院士, 研究方向为农业水土工程和早区农业节水; E-mail: kangsz@cau.edu.cn 资助项目：中国工程院咨询项目“国际化绿色化背景下国家区域食物安全可持续发展战略研究” (2016-ZD-09)

本刊网址： www.engineering.org.cn/ch/journal/sscae 


\section{一、水资源短缺条件下华北地区农业发展的 成就与面临的主要问题}

\section{（一）水资源短缺条件下华北地区农业发展成就}

从全国范围来看, 华北地区具有政治、科技、 文化、经济、区位优势, 它的兴衰对我国政治稳 定、经济发展有着重要影响。本研究课题所涉及 的华北地区（包括京、津、冀、鲁、豫五省市）人 口占全国的 $24 \%$, 耕地占全国的 $17.9 \%$, 光热充 足、土地肥沃, 是我国重要的农牧业生产和商品粮 基地。华北地区农牧业年产值占全国近 25\%，种养 业是农业的主体，其中种植业产值占 $58 \%$ ，牧业产 值占 $32 \%$ 。2014 年粮食产量为 $1.397 \times 10^{8} \mathrm{t}$, 占全 国的 $23 \%$; 作物产量构成中粮食占 $60 \%$, 其次为水 果、蔬菜占 $34 \%$ 。在粮食作物中，小麦、玉米是华 北平原粮食生产的主体，小麦产量占粮食总产量的 $51 \%$ ，其次为玉米占 $40 \%$ 。华北地区在我国小麦生 产中占主导地位，2014 年小麦播种面积和产量分别 占全国的 $48.3 \%$ 和 $56.2 \%$, 小麦单产为 $406.8 \mathrm{~kg}$ / 亩 ( 1 亩 $\approx 666.667 \mathrm{~m}^{2}$ ), 明显高于全国 $349.6 \mathrm{~kg}$ / 亩的 平均水平。因此, 华北地区食物生产在国家食物安 全中占有十分重要的地位。

但还要认识到, 华北平原农业的成就是在水 资源严重短缺条件下取得的，该区域水资源量仅占 全国水资源总量的 $6 \%$ ，人均水资源、水土资源配 置比例均大大低于全国平均水平, 如海河流域人均 水资源占有量只有 $250 \mathrm{~m}^{3}$ ，不足全国平均水平的 $1 / 8$ 。由于该地区气候干旱导致的水资源量减少和 工业城市发展对水资源需求量的增加，华北农业用 水总量从 1998 年的 $5.603 \times 10^{10} \mathrm{~m}^{3}$ 下降到 2015 年 的 $4.234 \times 10^{10} \mathrm{~m}^{3}$, 减幅达 $24.4 \%$; 农业用水量占 该区域总用水量的比例从 1998 年的 $72.2 \%$ 下降到 2015 年的 $61.7 \%$ [1]。虽然农业用水总量逐年减少， 但随着农业生产条件改善, 作物产量不断提高, 如 小麦、玉米主产省份河北、河南、山东近 30 年粮 食总产增加了 $5.85 \times 10^{7} \mathrm{t}$, 粮食单产的大幅增加是 粮食总产增加的主导因素。粮食单产中小麦单产 增加了 $200.9 \mathrm{~kg}$ / 亩, 增幅达 $120 \%$; 玉米单产增加 了 $179 \mathrm{~kg}$ / 亩, 增幅达 $90 \%$ 。而随着粮食单产增加, 作物耗水量并没有明显增加, 得益于农业科技进步 和农业基础设施条件的大幅改善，实现了农业总用 水量降低条件下农业产出的不断增加。
华北平原农业在水资源短缺条件下，为国家 和区域食物安全及农村经济社会发展做出了重大贡 献, 但也带来了诸多生态环境负效应, 特别是多年 地下水超采形成的大幅度下降漏斗问题，威胁着该 区域灌溉农业的可持续发展 [2]。为了治理该区域 地下水超采问题，近几年华北平原在发展节水型农 业中, 认真落实习近平总书记在新时期的治水思路, 坚持 “节水优先、空间均衡、系统治理、两手发力”, 实施 “以水定地、以水定产、以水定发展”, 取得 了显著成绩。特别是 2014 年以来中央财政启动了 地下水严重超采区 “节水限采” 试点行动, 以 “节、 引、蓄、调、管” 五大工程为治理思路, 即大力发 展以节水灌溉为主的节水型社会, 合理引用外调水, 着力调整种植结构, 因地制宜、因水制宜, 禁限采 管理、水位水量双管控和完善法规体系, 形成从水 源到田间、从工程到农艺、从建设到运行的综合治 理体系。上述措施的实施, 取得了一些初步成效, 广大农民群众的节水意识明显增强，水是稀缺性资 源、水资源有偿使用的理念逐步形成。试点区地下 水超采得到一定遏制, 在地下水超采综合治理方面 积累了一些经验。未来, 随着京津冀一体化和城镇 化发展，华北平原农业用水会进一步向工业城镇转 移，水资源短缺将是制约华北农业可持续发展的关 键因素, 协调作物生产 - 水资源 - 生态环境的关系, 发展水资源短缺条件下的适水农业已成为一个亟需 解决的重大课题。

\section{（二）华北平原水资源短缺条件下农业发展面临的 主要问题}

目前，华北平原水资源短缺条件下农业发展主 要面临以下问题。

一是农业没有适水发展, 农业规模严重超过了 水资源承载能力, 导致了大范围地下水位降落漏斗 等生态环境问题。华北平原灌溉节水技术已研究推 广 30 多年，并没有改变地下水资源继续恶化的现 状，节水技术效应明显低于用水强度增加效应，甚 至出现了 “越节水越缺水” 的怪象, 作物种植结构 逐步单一化, 蔬菜、小麦、果树等需灌溉水较多的 作物种植比例持续增加，该区农业没有 “适水” 发 展是主要原因。

二是农业种植结构不合理, 高耗水的蔬菜水果 种植面积发展较快, 单位面积耗水强度逐年增大, 
高水、高肥、高产的生产模式导致了低品质、低价 格和低效益, 不仅浪费水肥资源, 而且造成环境污 染和产能浪费。

华北平原粮食种植比例由 1981 年的 $78.9 \%$ 下 降到 2014 年的 $66.3 \%$, 而高耗水的蔬菜和果树种 植比例分别增加 $11.1 \%$ 和 $4.1 \%$ 。目前华北平原蔬 菜生产量占全国的 $37 \%$ 、水果占 $29 \%$, 蔬菜成为仅 次于粮食作物的灌溉耗水大户。蔬菜灌溉用水量多, 不仅体现在蔬菜茬口多, 也体现在由于灌溉技术和 灌溉制度不合理引起的根层水分渗漏多、养分淋失 量大, 从而带来一系列环境问题。

三是农业节水补偿机制未形成，农业节水技术应 用推广驱动力不足, 农业节水技术服务体系不健全, 节水工程建设标准低, 影响了节水工程效益的发挥。

农业节水的受益人是全社会, 而农业节水直接 影响的主体是农民。由于灌溉水价低大田作物节水 仅使农民减少少量的水费成本, 经济效益非常有限, 大部分效益是全社会受益的生态效益, 而农民采用 先进的节水技术需要大量投入和增加生产成本, 所 以农业节水技术应用推广缺乏驱动力, 在实际生产 中没有体现出多节水多补偿, 缺乏长期有效的节水 激励和补偿机制, 影响了农民节水的积极性和对节 水技术使用的主动性。

四是农业用水监测网络未形成, 缺乏对区域农 业用水的有效监控, 特别是缺乏对严重超采区地下 水的监控, 影响了对区域农业用水总量和单位面积 耗水强度的有效控制。

农业用水准确计量是推动节水技术应用和实施 农业节水补偿的基础, 但华北地区目前 $95 \%$ 以上 的地表水灌区没有安装田间用水计量设备; 关系到 地下水压采策略实施的井灌区, 还未形成严格的取 水许可制度, 对地下水的开采基本上还处于无序状 态, 管理难度较大。

五是不同部门的政策与措施缺乏协调, 高效节 水灌溉技术与农艺节水技术配套不紧密, 缺乏可规 模化应用的标准化农业节水技术模式。

目前, 华北平原农业生产涉及到多个方面, 缺 乏部门之间的密切配合, 甚至出现了在地下水严重 超采区同一块农田执行着来自不同政府部门相互矛 盾的政策措施, 一方面是节水限采试点, 以水定地、 以水定产, 农田休耕和粮食去产能; 另一方面又是 建设高产粮仓、扩大种植面积和消耗更多水资源。
六是地下水严重超采区节水限采试点资金投入 巨大, 但效果有限, 而且某些补贴政策的节水限采 效果不可持续。

综上, 华北地区农业可持续生产的最大制约因 素就是水资源。本文在研究课题大目标下, 将系统 分析 1998-2015 年华北水资源、农业用水、用水 效率的发展状况和未来发展方向, 为国际化绿色化 背景下华北地区食物安全可持续发展中农业水资源 的保障提供科学决策的基础。

\section{二、华北地区农业水土资源利用状况分析}

\section{（一）华北地区水资源量的变化状况}

华北地区五省 (市) 和全区近 18 年来平均降 水量与常年（1956-2000 年系列平均值）降水量相 比, 都有所下降 (见图 1), 但总体下降的幅度不大。 其中北京下降 $15.6 \%$, 幅度最大; 天津下降 5.2\%, 河北下降 9.6\%, 山东提高 $0.3 \%$, 河南下降 $1.9 \%$, 整个华北地区下降 $3.9 \%$ 。对多年降水的频率分析 表明, 五省（市）以及全区的偏丰水年和平水年出 现的频率在近年（2011-2015 年）明显偏多。说明 近几年全区的降水形势属于偏丰的状态。这种偏丰 的降水形势能否持续下去, 取决于气候变化的程度。 但目前最新的相关研究预测 [3], 华北地区在未来 30 年将进入一个降水偏丰的时期。

尽管 1998-2015 年的降水量下降幅度不大, 但是由于经济快速成长, 城市化进程加快, 土地利 用方式发生了巨大的变化, 下垫面情况改变巨大, 严重影响了降水所形成的地表水和地下水的数量。 华北五省 (市) 和全区地表水资源形成量下降幅度 巨大 (见图 2), 其中北京和河北分别下降 54.4\% 和 $52.7 \%$, 下降一半还多。天津下降 $21.8 \%$ 。河南下 降 $13.8 \%$, 山东下降 $6.7 \%$, 全区下降 $16.7 \%$ 。作为 粮食主产省的河北地表水资源量下降 $52.7 \%$, 势必 对该省的各部门用水以及农业用水产生负面影响。

降水形成的地下水资源量 1998-2015 年 来呈现波动下降态势, 1998-2007 年, 无论总量 还是占比的变化都波动较大, 2008-2015 年则呈 现稳步下降的趋势, 总量从 $5.89 \times 10^{10} \mathrm{~m}^{3}$ 下降到 $4.45 \times 10^{10} \mathrm{~m}^{3}$, 降幅达 $24.4 \%$, 地下水资源量占全 国的比例从 $6.27 \%$ 下降到 $5.71 \%$ (见图 3)。

总体上，华北地区水资源量从 1998 年的 


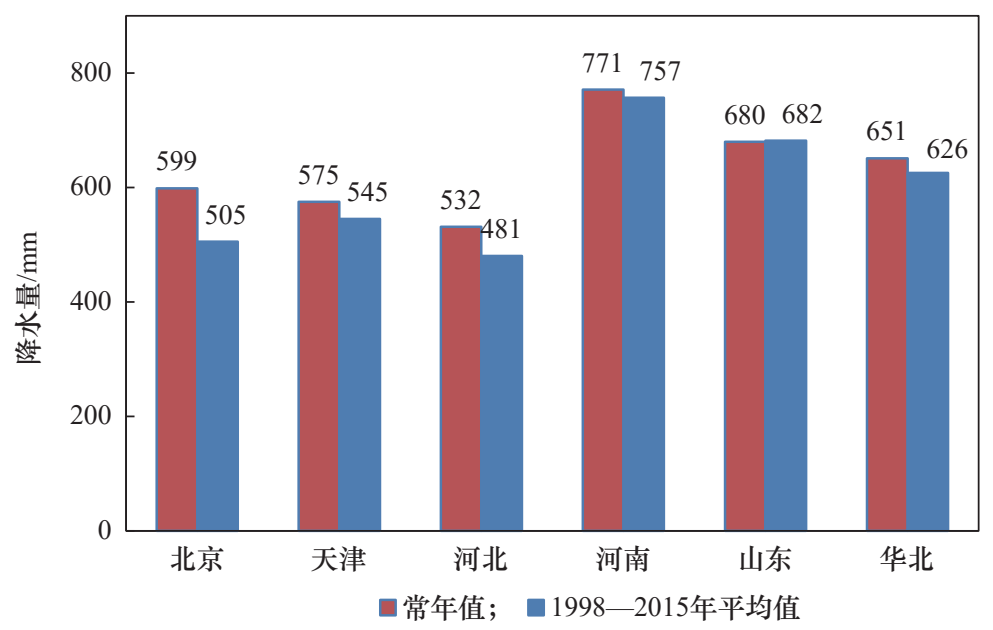

图 1 华北五省（市）及全区 1998一-2015 年平均降水量和常年（1956-2000 年系列平均值）降水量比较

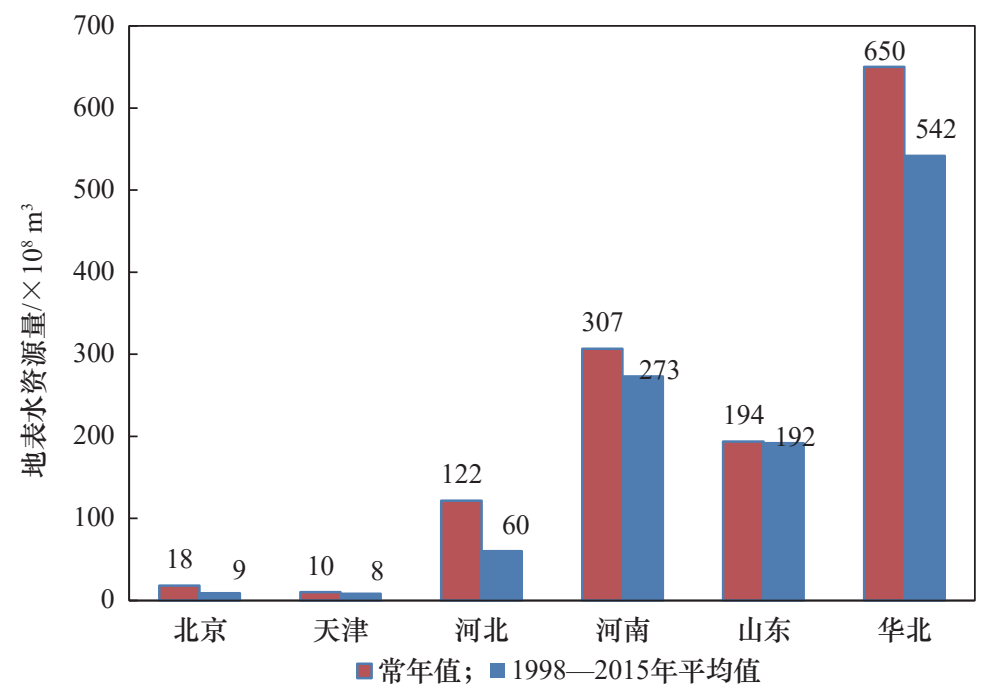

图 2 华北五省（市）及全区1998一-2015 年平均地表水资源量和常年地表水资源量比较

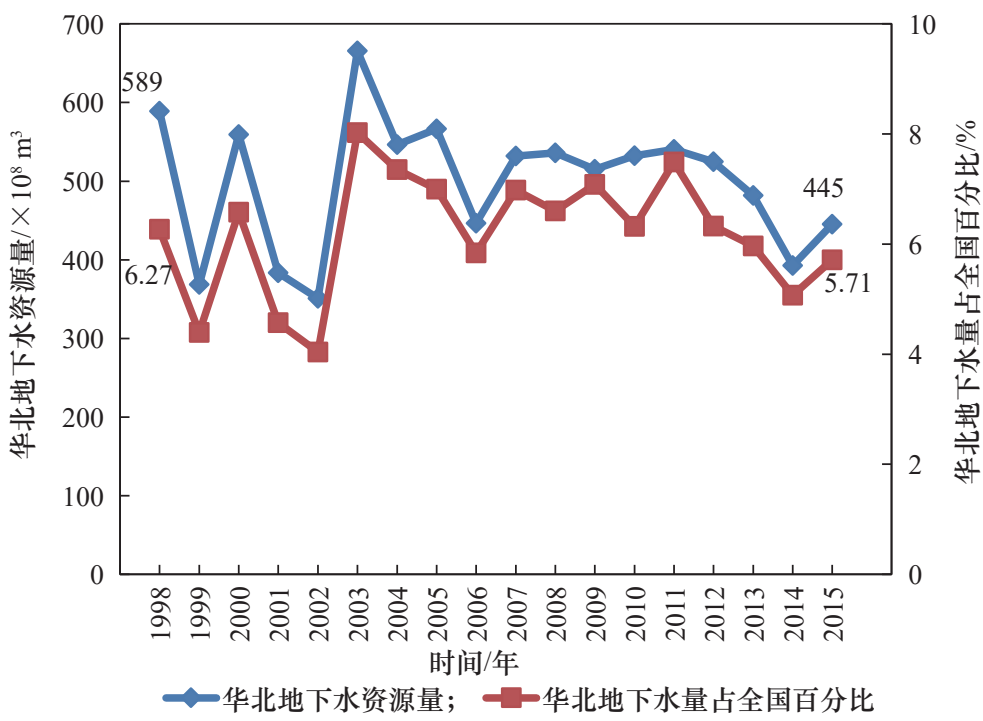

图 3 华北地区地下水资源量变化以及占全国地下水资源占比的变化 
$1.212 \times 10^{11} \mathrm{~m}^{3}$, 下降到 2015 年的 $6.303 \times 10^{10} \mathrm{~m}^{3}$ ， 降幅达 48.0\% (见图 4)。以上结果表明, 虽然近几 年华北地区降水形势偏丰, 但由于下垫面发生的巨 大变化, 降雨形成的水资源总量却下降了将近一半。 由此, 农业可以利用的水量受到了极大限制。

同时, 人口增长也加剧了水资源的紧张。华北 地区人均水资源量从 1998 年的 $450 \mathrm{~m}^{3} /$ 人, 下降到 2015 年的 $207 \mathrm{~m}^{3} /$ 人, 减幅达 $54.0 \%$ (见图 5), 这 种下降幅度是惊人的。

根据这些年来的水资源年型分类计算的人均水 资源量分别为: 丰水年 (1998 年、2003 年) 平均 人均水资源量为 $478 \mathrm{~m}^{3} /$ 人; 偏丰水年 (2000 年、 2004 年、 2005 年、 2007 年、 2010 年) 平均人均水
资源量为 $373 \mathrm{~m}^{3} /$ 人; 平水年 $(2008$ 年、 2009 年、 2011 年、 2012 年) 平均人均水资源量为 $302 \mathrm{~m}^{3} /$ 人; 偏枯水年 $(2001$ 年、 2006 年、2013 年、2014 年、 2015 年) 平均人均水资源量为 $214 \mathrm{~m}^{3} /$ 人; 枯水年 (1999 年、2002 年) 平均人均水资源量为 $189 \mathrm{~m}^{3} /$ 人。 虽然不同水文年型的人均水资源量差异较大，但总 体上, 华北地区人均水资源量占有很低, 即便在丰 水和偏丰水年也是如此。

同时, 耕地平均占有的水资源量, 综合不 同水文年型的数据计算可知, 丰水年平均为 $5585 \mathrm{~m}^{3} / \mathrm{hm}^{2}$; 偏丰水年平均为 $4558 \mathrm{~m}^{3} / \mathrm{hm}^{2}$; 平水年 平均为 $3746 \mathrm{~m}^{3} / \mathrm{hm}^{2}$; 偏枯水年平均为 $2771 \mathrm{~m}^{3} / \mathrm{hm}^{2}$; 枯水年平均为 $2234 \mathrm{~m}^{3} / \mathrm{hm}^{2}$ (见图 6)。可见, 不同

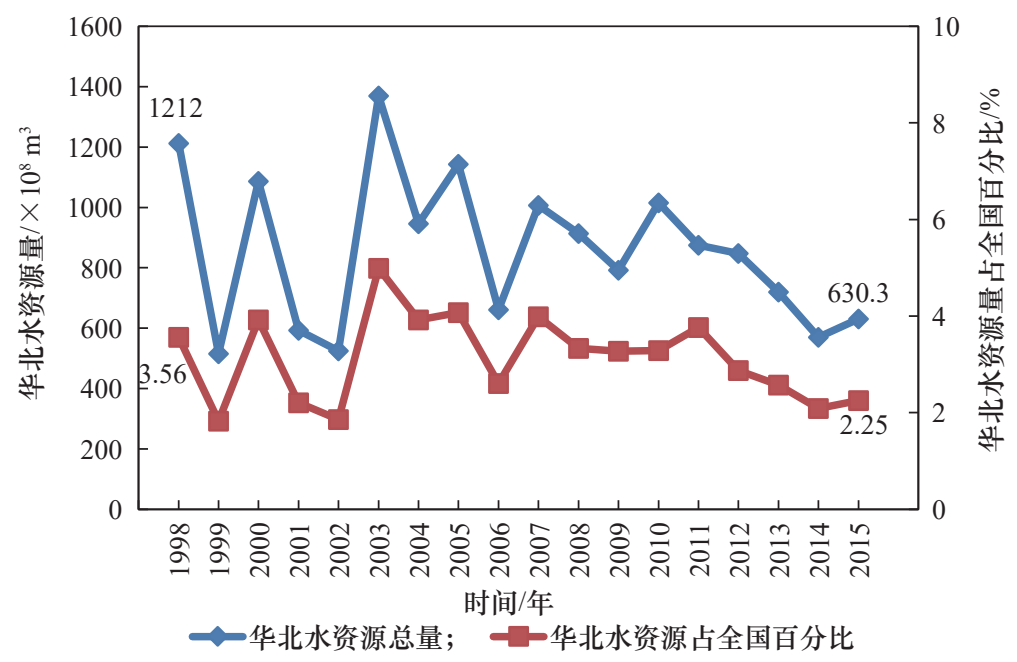

图 4 华北地区水资源总量变化以及占全国水资源总量占比的变化（1998-2015 年）

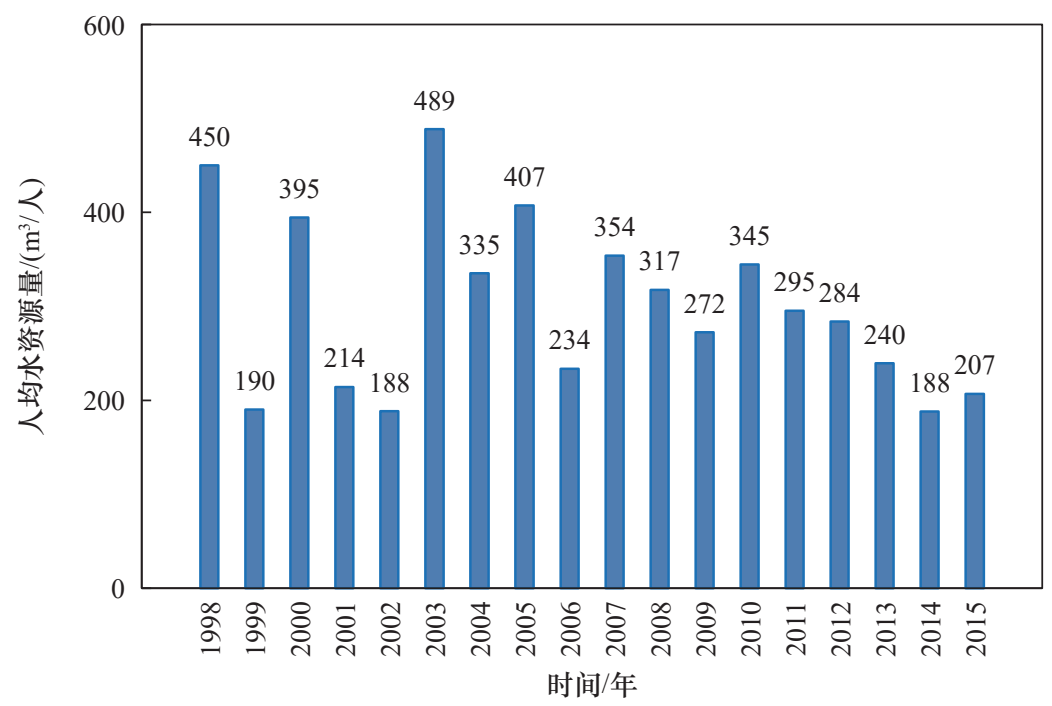

图 5 华北地区人均水资源量变化形势 
水文年型的耕地占有水资源量差距较大，丰水年是 枯水年的 2.5 倍; 偏丰水年是偏枯水年的 1.6 倍, 因此, 笔者认为, 平水年的 $3746 \mathrm{~m}^{3} / \mathrm{hm}^{2}$ 则更能代 表该区的耕地平均占有水资源量状况。

总体上，华北地区水资源形势较为紧张，在降 水量适度增加、水资源量大幅下降、经济快速发展、 人口增长等多重因素的综合影响下，华北地区的农 业用水形势和水土资源匹配形势都更加严峻。

\section{（二）华北地区的广义农业可用水量}

为解决从纯粹雨养农业到完全灌溉农业之间的 连续谱系中的农业生产用水问题, 在相关研究全球 农业用水范式变迁的核心概念的基础上, 建立了新 的中国农业用水分析综合框架。该分析框架从蓝水 和绿水概念出发, 提出并定义了 “广义农业水资源” 的概念 [4 6]。它由两个分量组成, 即耕地降水量 和耕地灌溉量。耕地降水量是指天然降雨降落在耕 地上的水量, 即 “绿水” 分量; 而耕地灌溉量则是 耕地接受的灌溉水量, 即 “蓝水” 分量。

“蓝水” 指的是天然降水降落到地球表面形成 径流，进入河道、湖泊等天然地表水体以及补充到 天然地下水体的水。由于这部分的水资源可以被人 类肉眼可见, 所以被称之为 “蓝水”。天然降水中 的另外一部分直接降落于各种地表植被覆盖物上, 其中一部分被植被冠层截留并以蒸发的方式返回大 气, 另外部分直接降落于土壤表面。降落于土壤表
面的部分其中一部分以土壤表面蒸发的方式返回大 气, 而另外一部分则通过入渗进入土壤, 供给植物 生长发育的需要, 最终以植物蒸腾的方式返回大气。 以土面蒸发和植物蒸腾方式返回大气的部分总称为 植物的蒸散发。而土壤中储存的有效水由于其主要 功能是供给植物生长发育的蒸散发需要, 所以又被 称为 “绿水”。由于土壤中的 “绿水” 是以有效水 的形式储存起来的, 因此被称之为 “绿水库”。而 被植物蒸散发的部分就被称之为 “绿水流”。上述 分析表明, “蓝水” 和 “绿水” 对包括农作物在内 的绿色植物的生长发育以及生物量和最终经济产量 的形成都具有重要作用。因此, 在评价农作物可利 用的水量时要将 “绿水” 考虑在内。农业水资源不 仅包括耕地灌溉 “蓝水”，还应包括耕地有效降水 的 “绿水”。广义农业可用水资源是指农作物生长 发育可以潜在利用的耕地有效降水 “绿水” 资源和 耕地灌溉 “蓝水”资源的总和。

与 “广义农业可用水资源” 概念相对应的还有 一些主要概念：灌溉 (“蓝水”) 消耗率 (耗水率), 是指流域或区域范围内, 灌溉水被作物以蒸散发的 形式消耗的水量与灌溉引水量之比。降水 ( “绿水”) 消耗率（耗水率），是指在流域或区域范围内，降 落到耕地上的天然降水被作物以蒸散发的形式消耗 的水量与耕地降水量之比。灌溉 (“蓝水”) 贡献率, 是指在流域或区域范围内, 粮食生产中消耗的总蒸 散量中来源于灌溉的部分与总蒸散量之比。降水

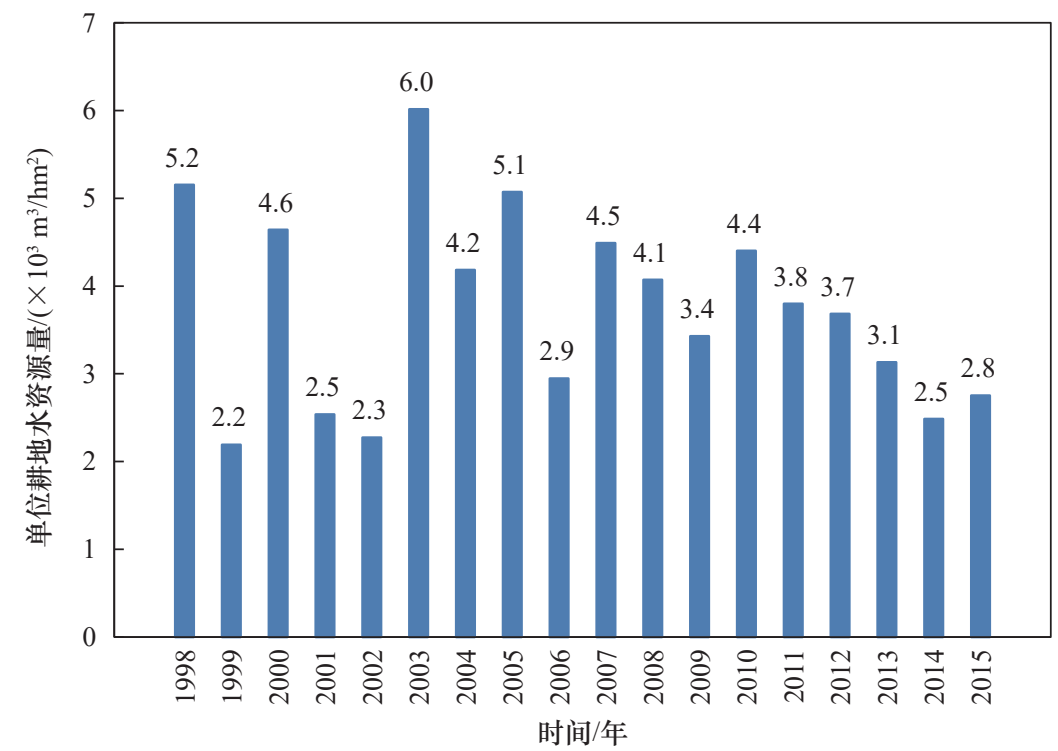

图 6 华北地区单位耕地平均水资源量变化 
（“绿水”）贡献率，是指在流域或区域范围内，粮 食生产消耗的总蒸散量中来源于降水的部分与总蒸 散量之比。水分生产力, 是指在流域或区域范围内, 粮食产量与生产过程中消耗的蒸散量之比。

根据上述概念模型建立的计算方法所计算结 果可知: 1998-2014 年, 华北广义农业水资源量 的最大值为 $1.927 \times 10^{11} \mathrm{~m}^{3}$, 出现在 2003 年 (丰水 年); 最小值为 $1.041 \times 10^{11} \mathrm{~m}^{3}$, 出现在 2002 年 (枯 水年)。其中, 耕地灌溉量最大值为 $5.27 \times 10^{10} \mathrm{~m}^{3}$, 出现在 1999 年 (枯水年); 最小值为 $3.54 \times 10^{10} \mathrm{~m}^{3}$, 出现在 2014 年 (偏枯水年)。耕地降水量最大值为 $1.523 \times 10^{11} \mathrm{~m}^{3}$, 出现在 2003 年 (丰水年); 最小值 为 $1.041 \times 10^{11} \mathrm{~m}^{3}$, 出现在 2002 年 (枯水年)。广 义农业水资源量在 18 年间平均值为 $1.647 \times 10^{11} \mathrm{~m}^{3}$,
其中耕地降水平均值为 $1.224 \times 10^{11} \mathrm{~m}^{3}$, 耕地灌 溉平均值为 $4.23 \times 10^{10} \mathrm{~m}^{3}$ (见图 7)。按水文年型 计算, 丰水年平均为 $1.816 \times 10^{11} \mathrm{~m}^{3}$, 偏丰水年为 $1.699 \times 10^{11} \mathrm{~m}^{3}$, 平水年为 $1.657 \times 10^{11} \mathrm{~m}^{3}$, 偏枯水 年为 $1.557 \times 10^{11} \mathrm{~m}^{3}$ ，枯水年为 $1.555 \times 10^{11} \mathrm{~m}^{3}$ 。

在广义农业可用水资源量中, “绿水” 和 “蓝水” 的相对比例在 $20 \%$ \% $80 \%$ 波动, 降水占比最大值为 $79.1 \%$, 出现在 2003 年 (丰水年); 灌溉占比最大 值为 $33.2 \%$, 出现在 1999 年（枯水年）; 降水占比 最小值为 $66.8 \%$, 出现在 1999 年（枯水年）; 灌溉 占比最小值为 $20.9 \%$, 出现在 2003 年 (丰水年) (见 图 8)。由上述结果可以明显看出, 随着水文年型的 不同，广义农业水资源中 “蓝” “绿” 成分的相对 比例是 “此消彼涨” 或 “此涨彼消” 的。

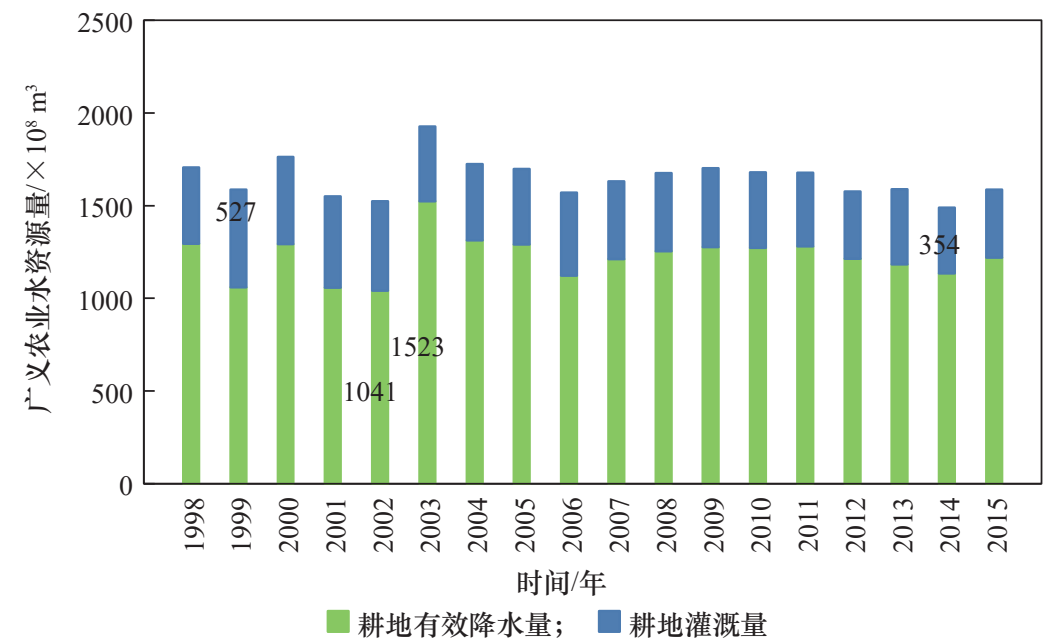

图 7 华北地区广义农业水资源量及其分量变化趋势

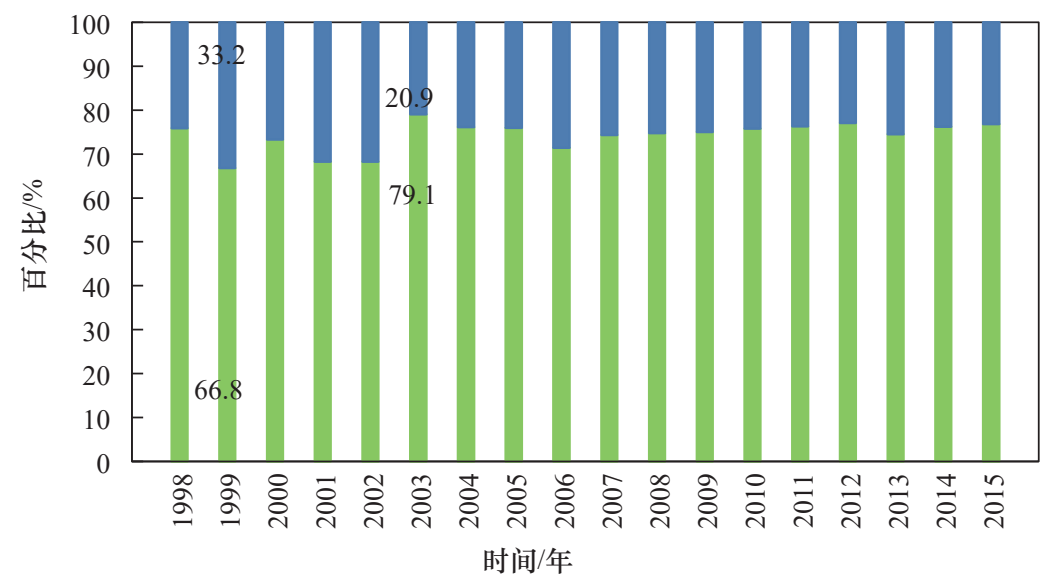

耕地降水绿水比例; 耕地灌溉蓝水比例

图 8 华北地区耕地灌溉和降水相对比例的变化趋势 


\section{（三）华北地区农业用水历史和现状}

华北农业用水总量从 1998 年的 $5.603 \times 10^{10} \mathrm{~m}^{3}$ 下降到 2015 年的 $4.234 \times 10^{10} \mathrm{~m}^{3}$, 减幅为 $24.4 \%$ 。 而农业用水量占该区总用水量的比例则从 1998 年 的 $72.2 \%$ 下降到 2015 年的 $61.7 \%$ 。该区农业用水 量占全国农业用水总量的比例从 1998 年的 $14.9 \%$ 下降到 2015 年的 $11.0 \%$ 。在农业用水总量中，农田 灌溉所占比例最大，一直在 $90 \%$ 95\% 波动，但是 农田灌溉占农业总用水量中的比例一直处于下降趋 势。由于目前还没有确切的有关农田灌溉和农业 中其他部门用水量的数据, 所以本文采用的是种 植业中各种作物的灌溉面积来概括农田灌溉的历 史和现状。

华北地区灌溉总面积从 1998 年的 $1.523 \times 10^{7} \mathrm{hm}^{2}$ 增加到 2015 年的 $1.602 \times 10^{7} \mathrm{hm}^{2}$ ，增幅达 $5.1 \%$; 占耕地总面积的比例从 1998 年的 $45.0 \%$ 提高到了 2015 年的 $55.7 \%$ 。

华北地区农田有效灌溉面积从1998 年的 $1.436 \times 10^{7} \mathrm{hm}^{2}$ 增加到了 2015 年的 $1.507 \times 10^{7} \mathrm{hm}^{2}$; 占耕地总面积的比例从 1998 年的 $61.1 \%$ 提高到了 2015 年的 $65.8 \%$ 。而农田有效灌溉面积占总灌溉面 积的比例则从 1998 年的 $94.2 \%$ 下降到 2015 年的 $92.7 \%$ 。从灌溉的内部结构来看, 耕地灌溉占比有 所下降，林地灌溉比例增幅最大，其他灌溉基本维 持原状。

在华北农田有效灌溉面积占华北耕地面积比例 适度提高、农田灌溉面积不断提高、农田灌溉面积 占总灌溉面积有小幅下降的情况下，华北农田灌溉 量却在稳步下降。从 1998 年的 $4.512 \times 10^{10} \mathrm{~m}^{3}$ 下降 到 2015 年的 $3.942 \times 10^{10} \mathrm{~m}^{3}$ 。平均不同水文年型的 农田灌溉量, 丰水年平均为 $4.39 \times 10^{10} \mathrm{~m}^{3}$, 偏丰水 年为 $4.19 \times 10^{10} \mathrm{~m}^{3}$, 平水年为 $4.2 \times 10^{10} \mathrm{~m}^{3}$, 偏枯 水年为 $4.67 \times 10^{10} \mathrm{~m}^{3}$, 枯水年为 $5.23 \times 10^{10} \mathrm{~m}^{3}$ 。因 此, 华北地区农田灌溉量的下降, 一方面是由于自 2003 年以来，只有两个偏枯年份，其余年份都是平 水或偏丰年份; 另外一方面是由于农田节水灌溉技 术的大面积推广。

\section{（四）华北粮食生产中“绿水”和“蓝水”贡献率}

本文还计算了华北五省（市）四大粮食作物（水 稻、玉米、小麦、大豆）产量中 “绿水” 和 “蓝水” 的贡献率。结果显示, 在华北粮食生产中, 绿水贡
献率在 $60.9 \% \sim 69.3 \%$, 平均为 $65.5 \%$; “蓝水” 贡献 率在 $30.7 \% \sim 39.1 \%$, 平均为 $34.5 \%$ 。即在主要粮食 作物的生产中, “绿水” 贡献约六成半, “蓝水” 贡 献约三成半。从水文年型分析，在丰水年，灌溉 平均贡献率为 $34.0 \%$, 降水平均贡献率为 $66.0 \%$; 在偏丰水年，灌溉平均贡献率为 $33.0 \%$, 降水平 均贡献率为 $67.0 \%$; 在平水年, 灌溉平均贡献率 为 $33.2 \%$, 降水平均贡献率为 $66.8 \%$; 在偏枯水 年, 灌溉平均贡献率为 $35.4 \%$, 降水平均贡献率为 $64.6 \%$; 在枯水年，灌溉平均贡献率为 $39.0 \%$, 降 水平均贡献率为 $61.0 \%$ 。综上，华北地区灌溉和降 水对粮食生产耗水的相对贡献率的变化与水文年型 是基本吻合的。但丰水年和偏丰水年的灌溉贡献率 并未比平水年有很大程度的降低, 这也许是多水年 份用水紧张缓解后，反而会提高用水量，这与国内 外许多对节水灌溉的研究所得出的 “越节水越用水” 的结论有可类比之处 [7 9]。

\section{（五）全国及华北地区粮食生产耗水和水分生产力}

粮食生产耗水量是指在粮食作物经济产量形成 过程中消耗的实际蒸散量。水分生产力是指粮食作 物单位耗水量所形成的经济产量。本文计算的粮食 作物水分生产力是水稻、小麦、玉米、大豆四大粮 食作物的混合水分生产力, 由于四大粮食作物在粮 食生产中的占比一直稳定在 $90 \%$ 以上, 因此, 这 四大粮食作物的水分生产力可以代表粮食生产的总 体耗水和水分生产力情况。

一般观点认为发展节水农业会在保证粮食产 量稳定增长满足消费需求的前提下减少农业用水消 耗，从而明显节约农业水资源。实际上，节水农业 在相当长的时期内远不能达到此效果, 在粮食总产 量基数已经很大的情况下, 大面积的粮食增产肯定 会增加耗水量, 用水量也会相应增加。本研究的计 算结果也印证了这一结论: 2004-2015 年，中国粮 食生产实现 “十二连增”, 其中四大粮食作物总产 也连年增长, 而同期的四大粮食作物总耗水量也在 同步增长。但增长幅度明显放缓, 说明水分生产力 的同步提高。

因为从 1998 年我国粮食生产达到历史最高值 后开始了连续几年的下滑，一直到 2003 年，华北 地区也不例外, 也有类似的下滑趋势。因此在分析 计算水分生产力的时候，排除 1998-2003 年的数 
据，而仅计算粮食生产恢复增长后的情况。2004一 2015 年, 华北地区四大粮食作物总的水分生产力 从 $1.275 \mathrm{~kg} / \mathrm{m}^{3}$ 提高到 $1.801 \mathrm{~kg} / \mathrm{m}^{3}$, 提高幅度达 $41.3 \%$ 。水分生产力的提高与多种因素相关, 其中 最重要的因素就是粮食作物单产水平的提高。华北 地区四大粮食作物总的单产水平已经从 2004 年的 $4.95 \mathrm{t} / \mathrm{hm}^{2}$ 提高到了 2015 年的 $5.98 \mathrm{t} / \mathrm{hm}^{2}$, 增幅达 $20.7 \%$ 。作物单产和水分生产力之间具有明显的相 关关系（见图 9)。

2015 年, 全区的水土资源高度不匹配。华北 耕地数量占全国的比例为 $16.96 \%$, 但是, 该区的 水资源却只占全国的 $2.25 \%$, 灌溉用水量占全国的 $10.74 \%$ 。其中情况最严重的是河北、河南、山东三 省, 河北省用仅占全国 $0.485 \%$ 的水资源耕种了全 国 4.83\% 的耕地, 而河南用仅占全国 $1.03 \%$ 的水 资源耕种了全国 $6.00 \%$ 的耕地, 山东则用仅占全国 $0.60 \%$ 的水资源耕种了全国 5.64\% 的耕地。19982015 年, 该区域一直维持这种水土资源格局。这种 水土资源的高度不匹配在目前高速发展的经济社会 背景下, 很难在短期内得以扭转, 也是华北地区食 物安全必须面对的重大挑战。

\section{三、战略对策建议}

根据以上结果, 综合本课题其他研究成果, 本 文提出以下相关战略对策建议。

第一, 结合当前深化农业供给侧结构性改革要 求, 对华北地下水严重超采区尤其是河北黑龙港地 区的粮食和蔬菜生产基地进行重新定位, 同时应充 分认识冬小麦的生态功能, 短期不宜大规模压缩小

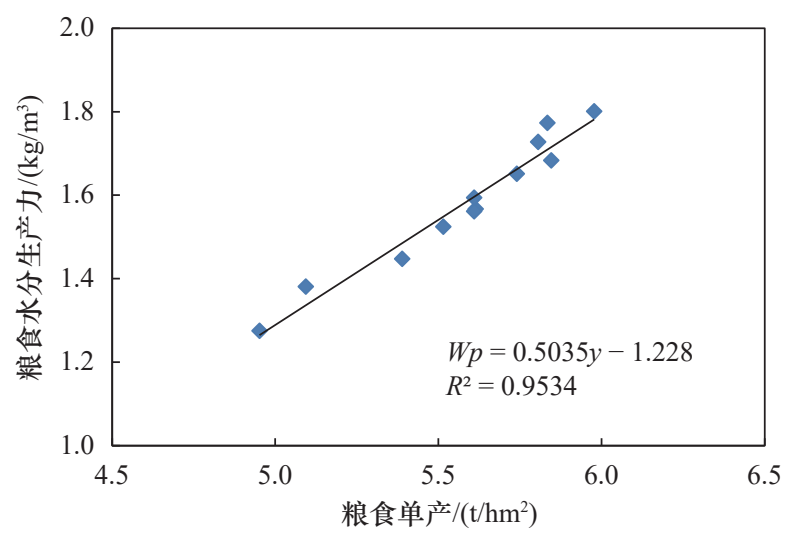

图 9 华北地区四大粮食作物单产和水分生产力之间关系
麦种植面积, 而应以水限产, 发展半旱地农业, 通 过提高小麦品质保障农民收入; 适当压缩高耗水蔬 菜产能, 建立适水农业种植结构。

第二, 要在严重缺水区降低熟制或发展半旱地 农业。针对深层地下水严重超采的河北省 51 个县、 天津 4 个区 (县); 山东 12 个县和河南的 6 个县, 共 73 个县 (区), 涉及耕地面积 $4.88 \times 10^{4} \mathrm{~km}^{2}$, 改变当前的 “冬小麦-夏玉米”一年两熟制为一 年一熟制。考虑到华北地区在我国小麦供应方面 的重要性以及冬小麦秋播后可形成有效的地表覆 盖层, 对减少冬春沙尘风险有重要作用, 可实施 冬小麦一年一熟种植, 或者实施足墒播种条件下 其他生育期不灌溉的小麦-玉米半旱地农业种植, 维持小麦 -玉米农田年耗水量在 550 600 mm, 可 实现这些区域深层地下水位不再下降。在此背景 下, 该地区粮食产量会降低 $2.2 \times 10^{10} \mathrm{~kg}$, 意味着 华北粮食产量将减产 $15.7 \%$, 相当于全国粮食总产 量减产 $3.6 \%$ 。

第三, 要在缺水区降低灌溉用水强度。研究表 明, 减少种植面积和熟制, 将增加土壤无效蒸发损 失, 对产量影响大, 而节水效果小于单位面积减少 灌溉水量的效果, 减少单位面积灌溉量对冬小麦产 量影响较小, 有限灌溉水用于扩大灌溉面积比单位 面积增加灌溉用水量对产量的影响更小, 降低单位 面积灌溉用水强度优于压缩灌溉面积。针对浅层地 下水超采的北京市 6 个区 (县)、天津市 9 个区 (县)、 河北省 50 个县、山东省 25 个县、河南 27 个县, 共 117 个县 (区), 涉及耕地面积为 $7.13 \times 10^{4} \mathrm{~km}^{2}$, 可保持当前的 “冬小麦-夏玉米”一年两熟制种植 制度不变, 实施冬小麦减少灌溉次数, 足墒播种, 拔节期灌溉一次, 干旱年在开花期追加一次灌水, 夏玉米产量保持不变, 冬小麦生育期减少耗水量 在 70 90 mm, 冬小麦产量会降低 $8.6 \times 10^{9} \mathrm{~kg}$, 占 华北粮食产量的 $6.1 \%$, 可基本实现浅层地下水采 补平衡。

第四, 要在水资源富裕区充分挖掘粮食增产潜 力。华北水资源严重短缺区粮食生产降低可通过黄 河和淮河流域水资源富裕区的粮食生产得到弥补, 通过在水资源相对丰富的江苏省 49 个县、山东省 16 个县、河南省南部的 45 个县, 共 110 个县, 涉 及耕地面积为 $1.128 \times 10^{5} \mathrm{~km}^{2}$, 通过技术进步提升 冬小麦和夏玉米单产并适度扩大小麦、玉米种植面 
积, 完全可弥补由于严重缺水区和缺水区粮食生产 减少带来的小麦、玉米产量降低。

第五, 要适度缩减蔬菜种植规模。针对华北 目前蔬菜供大于求的现状, 可压减蔬菜种植面积 $10 \% \sim 15 \%$ ，对区域蔬菜供应不会产生影响，在稳定 蔬菜价格和提升蔬菜品质基础上，不会影响农民收 益。而通过缩减蔬菜种植面积 $7 \times 10^{6} \sim 8 \times 10^{6}$ 亩, 一年可减少灌溉水消耗达 $2.5 \times 10^{9} \sim 3.0 \times 10^{9} \mathrm{~m}^{3}$, 对 减少地下水开采效果显著。

综上所述，华北地区近 20 年来，在水资源加 剧短缺和农业用水受到工业化、城市化和生态用水 的竞争和挤压下，依然取得了粮食连续增产。这应 归功于灌溉效率的不断提升、单产的连续提高、水 分生产力的持续增长。但是, 在气候变化影响下, 未来华北水资源形势仍不容乐观。同时，农业用水 还受到用水红线的制约, 而实现食物安全又必须要 有一定的水资源保障。在中央要求的 “一控两减三 基本” 的政策约束下，以往的高投入、大强度的农 业生产方式不可持续，但是经济发展、城市化和人 口增长的需求又必须满足，因此，华北地区的食物 安全必须转向依靠 “可持续集约”的生产和经营方 式。优化水土资源的匹配，加强对地下水超采的控 制、大力发展适水农业，向工程、农艺、制度节水 要效益, 实现多目标下国际化绿色化背景下华北食 物安全的水资源保障。
参考文献

[1] 中国水资源公报编辑委员会. 中国水资源公报(1998-2015年) [M]. 北京: 中国水利水电出版社, 1999-2016.

Compilation Committee of China Water Resource Bulletin. China water resource bulletin (1998-2015) [M]. Beijing: China Water Resource and Hydraulic Power Press, 1999-2016.

[2] 杨丽芝, 曲万龙, 刘春华. 华北平原地下水资源功能衰退与恢复 途径研究 [J]. 干旱区资源与环境, 2013, 27(7): 8-16.

Yang L Z, Qu W L, Liu C H. Groundwater functional degradation and rehabilitation in North China Plain [J]. Resource and Environment in Arid Regions, 2013, 27(7): 8-16.

[3] 任国玉, 任玉玉, 战云健, 等. 中国大陆降水时空变异规 律一一II. 现代变化趋势 [J]. 水科学进展, 2015, 26(4): 451-465. Ren G Y, Ren Y Y, Zhan Y J, et al. Spatial and temporal patterns of precipitation variability over mainland China: II: Recent trend [J]. Advances in Water Sciences, 2015, 26(4): 451-465.

[4] Huang F, Li B G. Assessing grain crop water productivity of China using a hydro-model-coupled-statistics approach. Part I: Method development and validation [J]. Agricultural Water Management, 2010, 97: 1077-1092.

[5] Huang F, Liu Z, Ridoutt B G, et al. China's water for food under growing water scarcity [J]. Food Security, 2015, 7: 933-949.

[6] Huang F, Li B G. Assessing grain crop water productivity of China using a hydro-model-coupled-statistics approach. Part II: Application in breadbasket basins of China [J]. Agricultural Water Management, 2010, 97: 1259-1268.

[7] Perry C. Accounting for water use: Terminology and implications for saving water and increasing production [J]. Agricultural Water Management, 2011, 98: 1840-1846.

[8] Gómez C M, Pérez-Blanco C D. Simple myths and basic maths about greening irrigation [J]. Water Resources Management, 2014, 28: 4035-4044.

[9] Lecina S, Isidoro D, Playán E, et al. Irrigation modernization and water conservation in Spain: The case of Riegos del Alto Aragón [J]. Agricultural Water Management, 2010, 97: 1663-1675. 